\title{
Alteration of object recognition memory after chronic exposure to dichlorophenoxyacetic acid (2,4-D) in adult rats
}

\author{
Alteração da memória de reconhecimento de objetos após exposição crônica ao ácido \\ diclorofenoxiacético (2,4-D) em ratos adultos \\ Alteración de la memoria de reconocimiento de objetos tras la exposición crónica al ácido \\ diclorofenoxiacético (2,4-D) en ratas adultas
}

Received: 01/05/2021 | Reviewed: 01/06/2021 | Accept: 01/08/2021 | Published: 01/09/2021

\author{
Rose Meire Riçato Ueda \\ ORCID: https://orcid.org/0000-0003-4928-9477 \\ Universidade do Oeste Paulista, Brazil \\ E-mail: rose.ricato@hotmail.com \\ Verena Miranda de Souza \\ ORCID: https://orcid.org/0000-0003-4873-4663 \\ Universidade do Oeste Paulista, Brazil \\ E-mail: vemirandasouza@gmail.com \\ Letícia Rocha Magalhães \\ ORCID: https://orcid.org/0000-0001-5752-7477 \\ Universidade do Oeste Paulista, Brazil \\ E-mail: let.rocham@gmail.com \\ Rogério Giuffrida \\ ORCID: https://orcid.org/0000-0002-2380-4349 \\ Universidade do Oeste Paulista, Brazil \\ E-mail: rgiuffrida@unoeste.br \\ Gisele Alborghetti Nai \\ ORCID: https://orcid.org/0000-0003-1674-7371 \\ Universidade do Oeste Paulista, Brazil \\ E-mail: patologia@unoeste.br
}

\begin{abstract}
The described neurological symptoms associated with pesticide exposure include memory and concentration problems. Most experimental studies of the association between dichlorophenoxyacetic acid (2,4-D) and neurotoxicity have focused on brain development, and few have been conducted in adult animals. The aim of this study was to assess whether chronic oral or inhalation exposure to 2,4-D affects object recognition memory in adult rats. Forty albino Wistar rats were used and distributed into 4 groups $(\mathrm{n}=10)$ : $\mathrm{I}$ : animals nebulized with distilled water; O: animals receiving feed treated with nebulized distilled water; DI: animals nebulized with $9.28 \times 10^{-3}$ grams of active ingredient per hectare (g.a.i./ha) of 2,4-D; and DO: animals receiving feed treated with $9.28 \times 10^{-3} \mathrm{~g} \cdot \mathrm{a} . \mathrm{i} . / \mathrm{ha}$ of nebulized 2,4-D. The animals were exposed for 6 months. To assess recognition memory, the object recognition test was used. Compared to control animals, animals exposed to 2,4-D spent less time exploring objects (p <0.05) and obtained an object recognition index score of -1 . Route of exposure to 2,4-D had an effect only on the time spent exploring objects, which was shorter in animals exposed orally. Chronic exposure to a high concentration of 2,4-D alters the ability of adult animals to recognize objects.
\end{abstract}

Keywords: Agrochemicals; Herbicides; Memory disorders; Neuropsychological tests; Repetition priming.

\section{Resumo}

Os sintomas neurológicos descritos associados à exposição a pesticidas incluem problemas de memória e concentração. A maioria dos estudos experimentais da associação entre ácido diclorofenoxiacético (2,4-D) e neurotoxicidade enfocou o desenvolvimento do cérebro, e poucos foram conduzidos em animais adultos. O objetivo deste estudo foi avaliar se a exposição oral crônica ou inalatória ao 2,4-D afeta a memória de reconhecimento de objetos em ratos adultos. Foram utilizados 40 ratos albinos Wistar, distribuídos em 4 grupos $(\mathrm{n}=10)$ : I: animais nebulizados com água destilada; O: animais recebendo ração tratada com água destilada nebulizada; DI: animais nebulizados com 9,28 x 10-3 gramas de ingrediente ativo por hectare (g.a.i./ha) de 2,4-D; e DO: animais que receberam ração tratada com 9,28 x 10-3 g.a.i./ha de 2,4-D nebulizado. Os animais ficaram expostos por 6 meses. Para avaliar a memória de reconhecimento, foi utilizado o teste de reconhecimento de objetos. Em comparação com os animais controle, os animais expostos ao 2,4-D gastaram menos tempo explorando objetos (p <0,05) e obtiveram um índice de reconhecimento de objeto de -1. A rota de exposição ao 2,4-D afetou apenas o tempo despendido na 
exploração de objetos, sendo menor nos animais expostos por via oral. A exposição crônica a uma alta concentração de 2,4-D altera a capacidade dos animais adultos de reconhecer objetos.

Palavras-chave: Agroquímicos; Herbicidas; Distúrbios de memória; Testes neuropsicológicos; Priming de repetição.

\section{Resumen}

Los síntomas neurológicos descritos asociados con la exposición a pesticidas incluyen problemas de memoria y concentración. La mayoría de los estudios experimentales de la asociación entre ácido diclorofenoxiacético (2,4-D) y neurotoxicidad se han centrado en el desarrollo del cerebro y pocos se han realizado en animales adultos. El objetivo de este estudio fue evaluar si la exposición crónica por vía oral o por inhalación al 2,4-D afecta la memoria de reconocimiento de objetos en ratas adultas. Se utilizaron cuarenta ratas albinas Wistar y se distribuyeron en 4 grupos $(\mathrm{n}=10)$ : I: animales nebulizados con agua destilada; O: animales que reciben alimento tratado con agua destilada nebulizada; DI: animales nebulizados con 9,28 x 10-3 gramos de ingrediente activo por hectárea (g.i.a./ha) de 2,4-D; y DO: animales que reciben alimento tratado con 9.28 x 10-3 g.i.a./ha de 2,4-D nebulizado. Los animales estuvieron expuestos durante 6 meses. Para evaluar la memoria de reconocimiento se utilizó la prueba de reconocimiento de objetos. En comparación con los animales de control, los animales expuestos a 2,4-D pasaron menos tiempo explorando objetos $(\mathrm{p}<0,05)$ y obtuvieron una puntuación de índice de reconocimiento de objetos de -1 . La ruta de exposición al 2,4-D tuvo efecto solo en el tiempo dedicado a explorar objetos, que fue más corto en los animales expuestos por vía oral. La exposición crónica a una alta concentración de 2,4-D altera la capacidad de los animales adultos para reconocer objetos.

Palabras clave: Agroquímicos; Herbicidas; Trastornos de la memoria; Pruebas neuropsicológicas; Cebado de repetición.

\section{Introduction}

The herbicide dichlorophenoxyacetic acid (2,4-D), belonging to the class of phenoxyacetic acids, was developed in 1941 during the Second World War and has been commercially used in the United States since 1947. It was the first selective herbicide used in the cultivation of soybean, corn, wheat, sugarcane, pastures and rice to prevent and combat certain pests (Song, 2014).

Exposure to 2,4-D can occur directly during spraying or handling in professional or domestic applications and indirectly via residues in soil, air, water reserves or food (Carneiro et al., 2015; Raina-Fulton, 2014).

Human exposure to the herbicide 2,4-D has been associated with several harmful health effects, with 2,4-D exhibiting oncogenicity, reproductive toxicity, genotoxicity, mutagenicity and neurotoxicity and acting as an endocrine disruptor (Garabrant \& Philbert, 2002; Reregistration Eligibility Decision (RED), 2005).

Exposure to 2,4-D can cause several symptoms depending on the route of exposure. Symptoms of respiratory contamination include loss of appetite and weight, a burning sensation in the throat and effects on the central nervous system (RED, 2005). In cases of oral exposure, depending on the formulation, symptoms are similar to those of exposure to some central nervous system depressants, such as aromatic chlorinated hydrocarbons, sedative drugs or alcohol (RED, 2005).

Some studies have investigated the effects of 2,4-D exposure and the implications for the central nervous system. Studies with rats exposed subcutaneously or orally in an acute or subchronic manner have revealed degenerative changes in the central nervous system (Elo \& Ylitalo, 1979), depression in the operant response and ataxia (Schulze \& Dougherty, 1988), behavioral changes, depression, and lethargy. Furthermore, exposure to 2,4-D has been reported to affect the activities of serotonergic and dopaminergic substances in the brain and cerebrospinal fluid at high doses (Elo \& MacDonald, 1989) and to result in dysfunction of the neurotransmitters/neurohormones dopamine and serotonin in the brain (Bortolozzi et al., 2004). Epidemiological studies in humans suggest a relationship between the use of 2,4-D and the development of Parkinson's disease (Tanner et al., 2009).

The herbicide 2,4-D is widely used worldwide for the control of leaf weeds. There is evidence linking exposure to 2,4-D to changes in the central nervous system, behavior and the concentrations of neurotransmitters in the brain (Bortolozzi et al., 2002). The exposure of developing animals to 2,4-D decreases myelination, resulting in behavioral changes and oxidative 
stress (Ferri et al., 2007). However, studies evaluating the association between 2,4-D and neurotoxicity in adult animals, with fully developed brains, are scarce.

The objective of this study was to evaluate whether chronic exposure to 2,4-D orally or via inhalation at a concentration corresponding to a common concentration of environmental exposure for humans affects object recognition memory in rats.

\section{Methodology}

Animals used in research have been treated according to institutional guidelines and with the internationally accepted principles for laboratory animal use and care as found in the international guidelines, with due consideration to the alleviation of distress and discomfort. This study was approved by the Ethics Committee on Animal Use of the Universidade do Oeste Paulista (Protocol No. 4485).

This is a prospective, quantitative, interventional and experimental study (Pereira et al., 2018). This study was based on the studies of Mello et al. (2018) e Antunes \& Biala (2012).

Forty adult male Wistar rats (200-250 g) were used. The rats were housed in large plastic cages in an air-conditioned vivarium (temperature of $22 \pm 2^{\circ} \mathrm{C}$ ) under a 12-h light/12-h dark cycle and were randomly distributed into 4 groups ( $\mathrm{n}=10$ ): $\mathrm{I}$ : animals nebulized with distilled water; O: animals receiving feed nebulized with distilled water; DI: animals nebulized with $9.28 \times 10^{-3} \mathrm{~g}$ of active ingredient per hectare (g.a.i/ha) of 2,4-D; and DO: animals receiving feed nebulized with $9.28 \times 10^{-3}$ g.a.i/ha of 2,4-D (Mello et al., 2018).

Exposure to 2,4-D was achieved using a herbicide (Nortox SA, Arapongas, Paraná, Brazil) with the following composition: $806 \mathrm{~g} / \mathrm{L}$ dimethylamine salt of 2,4-dichlorophenoxyacetic $(80.6 \% \mathrm{~m} / \mathrm{v}), 670 \mathrm{~g} / \mathrm{L} 2,4-\mathrm{D}$ acid equivalent $(67.0 \%$ $\mathrm{m} / \mathrm{v})$ and $424 \mathrm{~g} / \mathrm{L}$ inert ingredients $(42.4 \% \mathrm{~m} / \mathrm{v})$. The concentration used in the study $\left(9.28 \times 10^{-3} \mathrm{~g} \cdot \mathrm{a} . \mathrm{i} / \mathrm{ha}\right.$, corresponding to $467.93 \mathrm{mg} / \mathrm{m}^{3}$ ) is one of the highest concentrations used in crops, so it was considered a high-exposure concentration.

The nebulization protocol for the animals and feed was performed as described by Mello et al. (2018) using two boxes (32x 24x $32 \mathrm{~cm}$ ), each connected to an ultrasonic nebulizer (Soniclear Ind. Com. Imp. E Exp. Ltda., São Paulo, Brazil). A dose adjustment was performed according to the box area to simulate environmental exposure.

Animals exposed by inhalation were nebulized for five consecutive days a week, simulating occupational exposure. The feed of the animals exposed orally was changed every two days, and each ration was treated the day before offer.

All animals were exposed for 6 months.

The object recognition test was carried out in a medium density fiberboard (MDF) box measuring $100 \times 100 \mathrm{~cm}$ between 08:00 and 17:00 (Antunes \& Biala, 2012), one day after the last exposure to the herbicide 2,4-D. The box was cleaned with $10 \%$ alcohol after each test.

The test room had a 15-W red light that provided 3 lux of lighting over the center of the apparatus. The experiments were recorded on video, for five minutes, using an 8 MP camera video resolution: $1080 \mathrm{p}(1920 \times 1080 \mathrm{px})$ oriented at the apparatus. Throughout each trial, the same observer stayed inside the room to perform the recording from a position higher than the box.

The test was divided into three sessions: habituation, training (one hour after the first session) and testing (24 h after training) (Figure 1). The habituation session (for habituation to the apparatus) occurred only once. Each animal was placed individually in the center of the apparatus without objects and allowed to explore for five minutes. After 60 min, the animal was again placed in the center of the apparatus and exposed to two identical objects (identical in size, shape and color), which were defined as familiar objects F1 and F2 (Lego ${ }^{\circledR}$ square toys -São Paulo, Brazil), for five minutes; this was the training session. The animal was placed in front of the objects facing the wall. Exploration behavior was considered to have occurred 
when the animal touched the object with their nose or front legs or approached within $2 \mathrm{~cm}$ of the objects.

After a retention interval of $24 \mathrm{~h}$, the test session took place. An animal was placed in the center of the apparatus and exposed to two objects in the same position as in the training session; however, whereas one of the objects was the same as one from the training session, called the familiar object, the second object was new (the unfamiliar object) (Lego ${ }^{\circledR}$ round toy -São Paulo, Brazil). The exposure time in the test session was five minutes. The exploration time of the objects was measured manually using a digital timer and used to calculate a recognition index using the following formula (Antunes \& Biala, 2012):

Exploration time for the unfamiliar object - Exploration time for the familiar object

Unfamiliar object time + Familiar object time

Where an index value of 1.0 denotes recognition of the new object, 0.0 denotes exploration of both objects, and -1.0 denotes no recognition of either object.

Figure 1. Design of the three object recognition test sessions: habituation, training and testing.

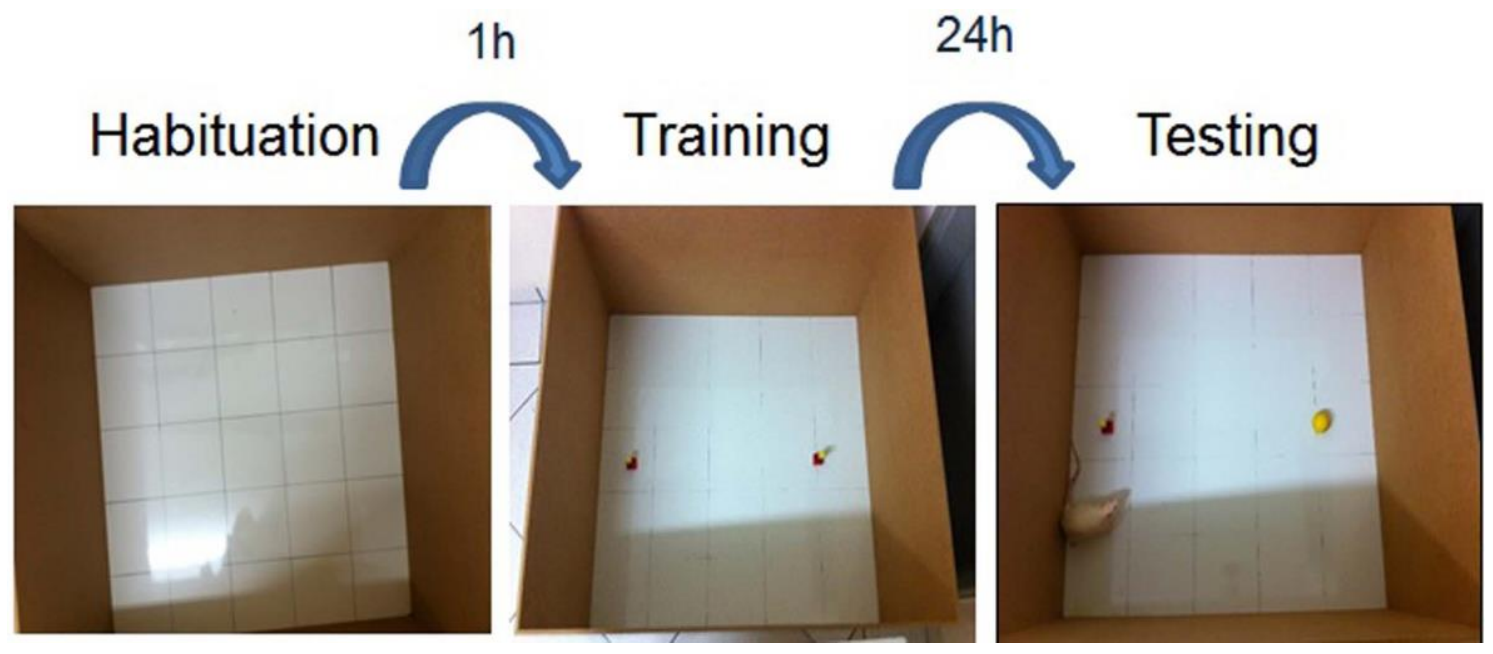

Source: Authors.

Figure 1 show the box used to carry out the tests and the sequence of them. In the first moment (Habituation session), the box does not contain objects, it only serves for the animal to get used to the environment. After an hour, the animal is placed back in the box that now contains two identical objects (Training session). Twenty-four hours later, the animal is placed in the box where one of the previous objects was exchanged for another (Testing session) to assess whether the animal's recognition memory.

The data were compared among groups by one-way analysis of variance with contrasts performed by the Tukey method. Validation of data normality and homoscedasticity assumptions was conducted using the Shapiro-Wilk and Levene tests, respectively. All analyses were conducted using the free software R with a 5\% significance level (R Development Core Team, 2019).

\section{Results}

In the testing session of the object recognition test, animals exposed to 2,4-D showed a shorter time to explore the objects than the control animals $(\mathrm{p}<0.05)$. Furthermore, among the herbicide-exposed animals, there was difference between exposure routes $(\mathrm{p}=0.012)$, with orally exposed animals exploring objects for less time than the animals exposed via 
inhalation (Fig. 2A). Regarding the animals' cognitive ability to discriminate the new object from the familiar object, the animals exposed to 2,4-D showed a negative index, showing a lesser ability to recognize the new object than the control animals; however, among 2,4-D-exposed individuals, there was no difference between exposure routes $(p=0.542)($ Fig. 2B).

Figure 2. A - Time engaged in object recognition by the study animals [in second(s)]. B - Recognition index scores of the animals in the study. I: animals nebulized with distilled water; O: animals receiving feed nebulized with distilled water; DI: animals nebulized with 2,4-D; DO: animals receiving feed nebulized with 2,4-D.
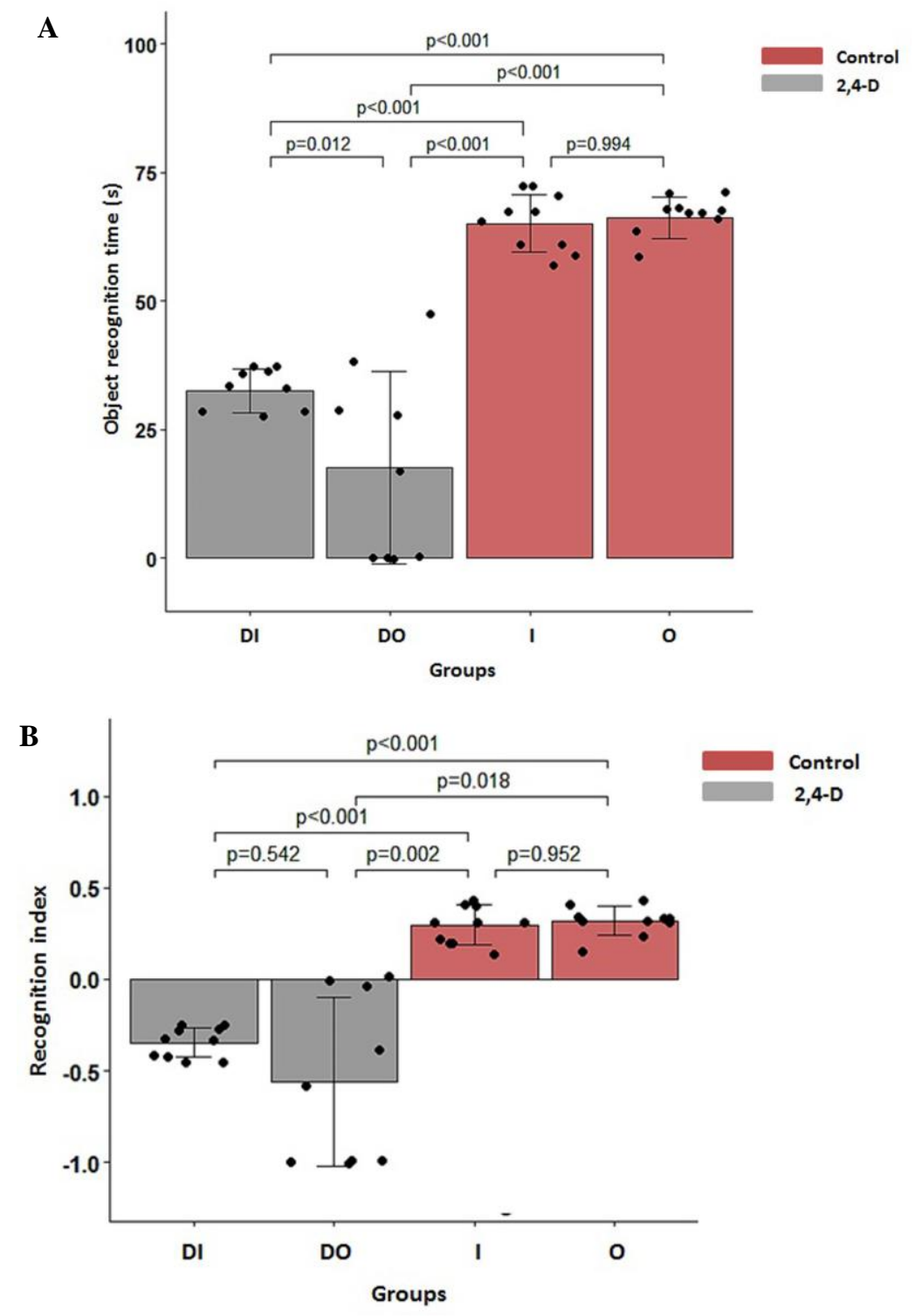

Source: Authors.

In Figure 2A, we can see that animals in the control group spent more time exploring objects than animals exposed to 2,4-D. When we evaluate only animals exposed to 2,4-D, those exposed orally explore the objects for less time than those exposed by inhalation. In Figure 2B, animals exposed to 2,4-D showed a negative recognition index, that is, they did not recognize the objects. In this analysis, also the animals exposed orally to 2,4-D had a lower index than those exposed by inhalation. This shows that the oral route has a greater impact on the ability to recognize objects than the inhalation route. 


\section{Discussion}

In this study, animals exposed to a high concentration of 2,4-D showed impairment of exploration and recognition memory for new objects in their environment. The impairment in exploration ability was greater for animals exposed orally than for those exposed via inhalation.

Memory is the acquisition, formation, conservation and evocation of information (Izquierdo, 2006). In the process of memory formation, there are four stages: coding, storage, consolidation and evocation (Kandel et al., 2014). Long-term memory is a form of memory in which information is stored for a long period. The establishment of long-term memory takes an average of three to eight hours. Before the completion of this process, the information to be consolidated may change due to the actions of drugs or to declines or increases in neurotransmitters, such as acetylcholine, dopamine and norepinephrine. The consolidation process occurs in the hippocampus, an area of the medial temporal lobe (Camina \& Guell, 2017). Declarative memory refers to the ability to archive and consciously retrieve information related to the experiences lived by the individual (Ullman, 2004). Declarative memory is susceptible to impairment by neuronal dysfunctions, which may be related to verbal, visual and recognition deficits (Tulving, 2002). In the present study, animals exposed to 2,4-D had impaired long-term memory, since $24 \mathrm{~h}$ after the training session, they did not recognize the objects.

Recognition memory covers a category of declarative memory, with two components: remembrance (wherein events are recalled in a conscious and contextualized way) and familiarity (referring to the exhibition of memory without contextualization). Memory is mediated by the hippocampus, and familiarity is mediated by the entorhinal and perirhinal regions (Vann et al., 2009). Injuries to the perirhinal cortex can interfere with object recognition memory (Aggleton et al., 2010).

In general, recognition memory is evaluated in animals by tests such as the object recognition test, which involves the presentation of a familiar object and a new object (Antunes \& Biala, 2012). The object recognition memory model proposed initially by Ennaceur and Delacour (1988) and later by Ennaceur (2010) has been used in rats and mice to assess cognitive deficits (Grayson et al., 2015) and to evaluate the effects of pharmacological and herbicide interventions and changes in recognition memory (Ait-Bali et al., 2020; Antunes \& Biala, 2012). The object recognition test allows the assessment of hippocampal function as well as the functioning of other cortical regions involved in object recognition (Antunes \& Biala, 2012).

Rodents have been used in object recognition tests to assess the neurotoxic effects of drugs; many drugs have been evaluated (Antunes \& Biala, 2012). Studies using the object recognition test in rodents indicate that rodents explore new objects longer than familiar ones over test retention intervals of 1, 5, 4 and $24 \mathrm{~h}$ (Mazumder et al., 2017). Our results showed that when the animals were subjected to chronic exposure to a high concentration of 2,4-D, they did not discriminate between the two types of objects, regardless of exposure type, and did not explore the new object as measured by time of exploration.

Several experimental studies have addressed the association of dichlorophenoxyacetic acid (2,4-D) and neurotoxicity in brain development (Evangelista et al., 1995; Duffard et al., 1996; Rosso et al., 1997; Bortolozzi et al., 1999; Rosso et al., 2000; Bortolozzi et al., 2004; Ferri et al., 2007; Carneiro et al., 2015). However, chronic exposure to 2,4-D occurs mainly among occupationally exposed workers engaged in agricultural activities (Zhang et al., 2011), that is, in the context of the adult (developed) brain. There is no description in the literature of injury assessment in the task of object recognition in animals exposed to 2,4-D. Therefore, in this study, we chose to evaluate adult animals and their ability to recognize objects following chronic exposure to $2,4-\mathrm{D}$.

The mechanism of action of chlorophenoxyacetic herbicides remains unclear. Chlorophenoxyacetic herbicides act on oxidative phosphorylation and metabolic routes involving acetyl coenzyme A, causing toxicity to the central nervous system (Bradberry et al., 2004). Some studies have shown that 2,4-D can cause oxidative stress in specific regions of the brain of 
newborn rats, such as midbrain, striate cortex and prefrontal cortex (Ferri et al., 2007). The impairment in object recognition memory observed in our study may have been due to the action of reactive oxygen species induced by 2,4-D in the perirhinal cortex and/or hippocampus.

\section{Conclusion}

In conclusion, chronic exposure to a high concentration of 2,4-D impairs the ability of adult animals to recognize objects. This data shows that the application of 2,4-D in crops must be done carefully, as its use can cause cognitive damage.

Complementary studies in adult animals exposed to various concentrations of 2,4-D that evaluate histological lesions and oxidative stress, demarcating those areas affected by 2,4-D in the adult brain, may clarify the pathogenesis of the impairment of object recognition memory when exposed to this herbicide.

\section{Acknowledgments}

This work was funded by research funds from the Universidade do Oeste Paulista (UNOESTE). V. M. Souza received a scholarship from the Scientific Initiation Scholarship Program of the National Council for Scientific and Technological Development (PIBIC / CNPq). The authors would like to thank Professor Rui Daniel Schroder Prediger of the Department of Pharmacology at the Federal University of Santa Catarina (Florianópolis, SC, Brazil) for the guidelines for carrying out the behavioral test.

\section{References}

Ait-Bali, Y., Ba-M'hamed, S., Gambarotta, G., Sassoè-Pognetto, M., Giustetto, M., \& Bennis, M. (2020). Pre- and postnatal exposure to glyphosate-based herbicide causes behavioral and cognitive impairments in adult mice: evidence of cortical ad hippocampal dysfunction. Archives of toxicology, 94(5), 17031723. 10.1007/s00204-020-02677-7

Aggleton, J. P., Albasser, M. M., Aggleton, D. J., Poirier, G. L. \& Pearce, J. M. (2010). Lesions of the rat perirhinal cortex spare the acquisition of a complex configural visual discrimination yet impair object recognition. Behavioral Neuroscience, 124(1), 55-68. 10.1037/a0018320

Antunes, M., \& Biala, G. (2012). The novel object recognition memory: neurobiology, test procedure, and its modifications. Cognitive processing, 13(2), 93110. 10.1007/s10339-011-0430-Z

Bortolozzi, A. A., Duffard, R. O., \& Evangelista de Duffard, A. M. (1999). Behavioral alterations induced in rats by a pre- and postnatal exposure to 2,4dichlorophenoxyacetic acid. Neurotoxicology and teratology, 21(4), 451-465. 10.1016/s0892-0362(98)00059-2

Bortolozzi, A., Duffard, R., Antonelli, M., \& Evangelista de Duffard, A. M. (2002). Increased sensitivity in dopamine D(2)-like brain receptors from 2,4dichlorophenoxyacetic acid (2,4-D)-exposed and amphetamine-challenged rats. Annals of the New York Academy of Sciences, 965, 314-323. 10.1111/j.17496632.2002.tb04173.x

Bortolozzi, A. A., Evangelista De Duffard, A. M., Duffard, R. O., \& Antonelli, M. C. (2004). Effects of 2,4-dichlorophenoxyacetic acid exposure on dopamine D2-like receptors in rat brain. Neurotoxicology and teratology, 26(4), 599-605. 10.1016/j.ntt.2004.04.001

Bradberry, S. M., Proudfoot, A. T., \& Vale, J. A. (2004). Poisoning due to chlorophenoxy herbicides. Toxicological reviews, 23(2), 65-73. 10.2165/00139709200423020-00001

Camina, E., \& Güell, F. (2017). The Neuroanatomical, neurophysiological and psychological basis of memory: current models and their origins. Frontiers in pharmacology, 8, 438. 10.3389/fphar.2017.00438

Duffard, R., Garcia, G., Rosso, S., Bortolozzi, A., Madariaga, M., di Paolo, O., \& Evangelista de Duffard, A. M. (1996). Central nervous system myelin deficit in rats exposed to 2,4-dichlorophenoxyacetic acid throughout lactation. Neurotoxicology and teratology, 18(6), 691-696. 10.1016/s0892-0362(96)00087-6

Elo, H. A., \& Ylitalo, P. (1979). Distribution of 2-methyl-4-chlorophenoxyacetic acid and 2,4-dichlorophenoxyacetic acid in male rats: evidence for the involvement of the central nervous system in their toxicity. Toxicology and applied pharmacology, 51(3), 439-446. 10.1016/0041-008x(79)90368-5

Elo, H. A., \& MacDonald, E. (1989). Effects of 2,4-dichlorophenoxyacetic acid (2,4-D) on biogenic amines and their acidic metabolites in brain and cerebrospinal fluid of rats. Archives of toxicology, 63(2), 127-130. 10.1007/BF00316434

Ennaceur, A., \& Delacour, J. (1988). A new one-trial test for neurobiological studies of memory in rats. 1: Behavioral data. Behavioural brain research, 31(1), 47-59. 10.1016/0166-4328(88)90157-X

Ennaceur, A. (2010). One-trial object recognition in rats and mice: methodological and theoretical issues. Behavioural brain research, 215(2), 244-254. 10.1016/j.bbr.2009.12.036 
Evangelista de Duffard, A. M., Brusco, A., Duffard, R., García, G., \& Pecci Saavedra, J. (1995). Changes in serotonin-immunoreactivity in the dorsal and median raphe nuclei of rats exposed to 2,4-dichlorophenoxyacetic acid through lactation. Molecular and chemical neuropathology, 26(2), 187-193. 10.1007/BF0281501

Ferri, A., Duffard, R., \& de Duffard, A. M. (2007). Selective oxidative stress in brain areas of neonate rats exposed to 2,4-dichlorophenoxyacetic acid through mother's milk. Drug and chemical toxicology, 30(1), 17-30. 10.1080/01480540601017629

Carneiro, F. F., Augusto, L. G. S., Rigotto, R. M. G., Friedrich, K., \& Búrgio, A. C. (2015). Dossiê ABRASCO: um alerta sobre os impactos dos agrotóxicos na saúde. Rio de Janeiro: EPSJV; Expressão Popular. https://www.abrasco.org.br/dossieagrotoxicos/wpcontent/uploads/2013/10/DossieAbrasco_2015_web.pdf

Garabrant, D. H., \& Philbert, M. A. (2002). Review of 2,4-dichlorophenoxyacetic acid (2,4-D) epidemiology and toxicology. Critical reviews in toxicology, 32(4), 233-257. 10.1080/20024091064237

Grayson, B., Leger, M., Piercy, C., Adamson, L., Harte, M., \& Neill, J. C. (2015). Assessment of disease-related cognitive impairments using the novel object recognition (NOR) task in rodents. Behavioural brain research, 285, 176-193. 10.1016/j.bbr.2014.10.025

Izquierdo, I., Bevilaqua, L. R., Rossato, J. I., Bonini, J. S., Medina, J. H., \& Cammarota, M. (2006). Different molecular cascades in different sites of the brain control memory consolidation. Trends in neurosciences, 29(9), 496-505. 10.1016/j.tins.2006.07.005

Kandel, E. R., Dudai, Y., \& Mayford, M. R. (2014). The molecular and systems biology of memory. Cell, 157(1), 163-186. 10.1016/j.cell.2014.03.001

Mazumder, A. G., Sharma, P., Patial, V., \& Singh, D. (2017). Crocin attenuates kindling development and associated cognitive impairments in mice via inhibiting reactive oxygen species-mediated NF- $\kappa$ B activation. Basic \& clinical pharmacology \& toxicology, 120(5), 426-433. 10.1111/bcpt.12694

Mello, F. A., Quinallia G., Marion. A. L., Jorge. F. C., Marinelli, L.M. Salge, A. K. M., \& Rossi e Silva, R. C. (2018). Evaluation of the nasal cavity mice submitted to the inhalation exposure to the herbicide 2,4-dichlorophenoxyacetic acid. Medicina (Ribeirão Preto, Online.), 51(4), 247-253. 10.11606/issn.21767262.v51i4p00-00

Pereira, A. S., Shitsuka, D. M., Parreira, F. J., Shitsuka, R. (2018). Metodologia da pesquisa científica. Ed. UFSM. https://repositorio.ufsm.br/bitstream/handle/1/15824/Lic_Computacao_Metodologia-Pesquisa-Cientifica.pdf?sequence=1 .

Raina-Fulton, R. (2014). A review of methods for the analysis of orphan and difficult pesticides: glyphosate, glufosinate, quaternary ammonium and phenoxy acid herbicides, and dithiocarbamate and phthalimide fungicides. Journal of AOAC International, 97(4), 965-977. 10.5740/jaoacint.sgeraina-fulton

Reregistration Eligibility Decision (RED). (2005). 2,4-D EPA 738-R-05-002. U.S. Environmental Protection Agency, Office of Prevention, Pesticides and Toxic Substances, Office of Pesticide Programs, U.S. Washington, DC: Government Printing Office. https://archive.epa.gov/pesticides/reregistration/web/pdf/24d_red.pdf

R Development Core Team. (2019). R Software: a language and environment for statistical computing. http://www.r-project.org

Rosso, S. B., Di Paolo, O. A., Evangelista de Duffard, A. M., \& Duffard, R. (1997). Effects of 2,4-dichlorophenoxyacetic acid on central nervous system of developmental rats. Associated changes in ganglioside pattern. Brain research, 769(1), 163-167. 10.1016/s0006-8993(97)00823-8

Rosso, S. B., Cáceres, A. O., de Duffard, A. M., Duffard, R. O. \& Quiroga S. 2,4- (2000). Dichlorophenoxyacetic acid disrupts the cytoskeleton and disorganizes the Golgi apparatus of cultured neurons. Toxicol Sci., 56(1), 133-140. 10.1093/toxsci/56.1.133

Schulze, G. E., \& Dougherty, J. A. (1988). Neurobehavioral toxicity of 2,4-D-n-butyl ester (2,4-D ester): tolerance and lack of crosstolerance. Neurotoxicology and teratology, 10(1), 75-79. 10.1016/0892-0362(88)90069-4

Song, Y. (2014). Insight into the mode of action of 2,4-dichlorophenoxyacetic acid (2,4-D) as an herbicide. Journal of integrative plant biology, 56(2), 106113. 10.1111/jipb.12131

Tanner, C. M., Ross, G. W., Jewell, S. A., Hauser, R. A., Jankovic, J., Factor, S. A., Langston, J. W. (2009). Occupation and risk of parkinsonism: a multicenter case-control study. Archives of neurology, 66(9), 1106-1113. 10.1001/archneurol.2009.195

Tulving, E. (2002). Episodic memory: from mind to brain. Annual review of psychology, 53, 1-25. 10.1146/annurev.psych.53.100901.135114

Ullman, M. T. (2004). Contributions of memory circuits to language: the declarative/procedural model. Cognition, 92(1-2), 231-270. 10.1016/j.cognition.2003.10.008

Vann, S. D., Tsivilis, D., Denby, C. E., Quamme, J. R., Yonelinas, A. P., Aggleton, J. P., \& Mayes, A. R (2009). Impaired recollection but spared familiarity in patients with extended hippocampal system damage revealed by 3 convergent methods. Proc Natl Acad Sci USA, 106 (13), 5442-5447. 10.1073/pnas.0812097106

Zhang, X., Acevedo, S., Chao, Y., Chen, Z., Dinoff, T., Driver, J., \& Krieger, R. (2011). Concurrent 2,4-D and triclopyr biomonitoring of backpack applicators, mixer/loader and field supervisor in forestry. Journal of environmental science and health. Part. B, Pesticides, food contaminants, and agricultural wastes, 46(4), 281-293. 10.1080/03601234.2011.559424 